\title{
Energy transition and path dependence: the case of Costa Rica
}

\section{Transición energética y dependencia de la trayectoria: el caso de Costa Rica}

\author{
Daniela García-Sánchez ${ }^{1}$ \\ Agencia de Cooperación Alemana,(GIZ), Costa Rica \\ Daniel Francisco Avendaño-Leadem ${ }^{2}$ \\ Universidad Nacional, Costa Rica
}

\begin{abstract}
Costa Rica's world known renewable energy model relies heavily on large scale hydropower, a source surrounded by strong environmental and social questionings. This condition of dependence has its own reinforcing processes that hinder advancements of alternative renewable technologies. In today's carbon-constrained world, new approaches - and new geographies - are required to ensure the availability and accessibility of sustainable energy services. Using path dependence theory developed within evolutionary economic geography and neoinstitutionalist school of thought, the present research offers an explanation of the specific path driven by the impact of historical events that favor hydropower in Costa Rica's energy transition.
\end{abstract}

Keywords: path dependence, energy transition, evolutionary economic geography, renewable energy

\section{Resumen}

El modelo de energía renovable mundialmente conocido de Costa Rica se basa en gran medida en la hidroelectricidad de gran escala, una fuente rodeada de fuertes cuestionamientos ambientales y

1 Economista ecológica con doctorado en ciencias políticas. Asesora del Proyecto ACCIÓN Clima II y Proyecto VICLIM del Deutsche Gesellschaft für Internationale Zusammenarbeit (GIZ) GmbH. Email: danielagarcia.s@gmail.com

2 Geógrafo con maestría en planificación urbana y regional y maestría en eficiencia de los recursos aplicado en la planificación. Académico de la Escuela de Ciencias Geográficas, Universidad Nacional, Costa Rica. Email: danavenda@gmail.com.

Este artículo corresponde a la ponencia presentada en el 35th Conference of Latin American Geographers realizada en San José, Costa Rica del 20 al 22 de mayo del 2018. 
sociales. Esta condición de dependencia tiene sus propios procesos que lo respaldan y dificultan el avance de tecnologías renovables alternativas. En el mundo actual, limitado por el carbono, se requieren nuevos enfoques - y nuevas geografías - para asegurar la disponibilidad y accesibilidad de los servicios de energía de forma sostenible. Usando la teoría de la dependencia de la trayectoria desarrollada dentro de la geografía económica evolutiva y de la escuela de pensamiento neoinstitucional, la presente investigación ofrece una explicación del camino específico impulsado por el impacto de eventos históricos que favorecen la energía hidroeléctrica en la transición energética costarricense.

Palabras clave: dependencia de la trayectoria, transición energética, geografía económica evolutiva, energía renovable

\section{Introduction}

Costa Rica is considered a leader in renewable energy generation particularly since over $90 \%$ of its electricity has been produced with renewable sources, mainly hydroelectricity. Despite non-conventional renewable sources (geothermal and wind) being introduced in the national energy system as a result of previous experimental projects and sector liberalization reforms during the late 1990s, these sources still play a secondary role in an energy mix in which solar energy has been almost absent. In contrast, the installed capacity of conventional technologies (hydroelectricity) has kept growing during the last decades even in contexts where alternative energy sources would perform better in terms of efficiency.

This domination occurs despite the fact that hydropower generation is vulnerable to the effects of climate change since it requires consistent rainfall. Costa Rica has suffered recent precipitation patterns that could eventually mean that the source that gave the country its "green energy" surge is likely to be restrained by climate change (Fendt, 2015). Additionally, there is an increased perception of problems and limitations surrounding the construction of large hydroelectric dams since they cause considerable environmental and social degradation. These impacts have triggered the involvement and opposition of environmental and grassroots' organizations who claim dams affect previously healthy watersheds by disrupting wildlife and displacing indigenous communities.

Conversely, sustainable alternatives such as solar energy have been relegated within the national energy system's trajectory despite having advantages considering that its technological development has improved its efficiency and cost. Even though photovoltaic energy is the world's fastest growing power- generation technology and is supported by multiple actors 
globally, it is being underestimated within the energy matrix of a country considered one of the world leaders in renewable electricity generation. Costa Rica's commitment to Carbon Neutrality by the year 2021 raised expectations for the implementation of $100 \%$ renewable energy within the electricity sector by taking advantage of the solar energy potential. This opened a window of opportunities for creative and/or radical changes to take place. Unfortunately, this has not occurred and therefore it is important to understand why.

Common research interests between human geography and energy studies represent an opportunity for carrying out an in depth examination for understanding the relationship between different trajectories of energy transition and the geographical conditions from which they emerge (Massey, 2005). By considering Costa Rica as an empirical case study and applying theories shared between the fields of economic geography and neoinstitutional theories, this research analyzes the development of Costa Rica's energy matrix by identifying three forms of path dependence mechanisms: a) technological lock-in; b) positive externalities; and c) institutional hysteresis. On the verges of achieving carbon neutrality within the electricity sector (the country generated $99 \%$ of its electricity with renewables during 2017), this article sheds light to understand a pathway that is difficult to reverse despite the issues surrounding the exploitation of conventional sources.

\section{Theoretical framework}

Human geographers describe 'territoriality' as the social and political power being organized and exercised over space (Brenner et al., 2003). This concept applies to the geographical strategies of separation and integration implemented by economic and political actors in the exercise of authority and/or commercial power (Brenner, 2004). Infrastructure systems of energy generation, transmission and distribution are spatially constituted and have been territorialized in diverse ways over time.

In this sense, the territorialization of the energy transition process is evidenced in two ways. On the one hand, by the distribution of diverse energy-related activities across a particular space and the causal processes giving rise to these configurations; on the other hand, by the geographical connections and interactions between that space and other spaces (i.e. 
Costa Rica's position in a broader political economy of states, transnational firms, international agreements, and NGO's).

Examining energy transition is therefore a geographical process as it involves the reconfiguration of current patterns and scales of economic and social activity. Energy systems are spatially constituted and therefore their transition requires geographical interpretation considering the system's components are embedded in particular settings and the resulting network produces geographies of connection, dependency and control (Emmerson $\&$ Stevens, 2012).

Theoretical developments in the field of energy transition have lacked appreciation towards the importance of history within the economic landscape, as they do not offer an interpretation on how such landscape evolves over time. An evolutionary perspective is therefore necessary to a fuller understanding of issues such as the geographies of technological progress, dynamic competitive advantage, economic restructuring, and economic growth. This context offers fertile land for applying and extending the ideas and concepts from evolutionary economics within the analysis of regional and urban development (Boschma \& Martin, 2012).

Evolutionary economics focuses on the processes and mechanisms by which the economy self-transforms itself from within by means of historical processes of change and development (Witt, 2003). It discusses how actors and institutions have developed long-lasting routines and habits, attaining a quasi-genetic character, with the market functioning as an important selection mechanism (MacKinnon et al., 2009).

The purpose of employing such concepts, theories, and methodologies within economic geography is to utilize them in the interpretation and explanation of historical landscape changes. This also serves to demonstrate how the understanding of the processes driving economic evolution is enhanced by situating the economy in space, that is, to reveal how geography matters in determining the nature and trajectory of the economic system's evolution.

Within evolutionary economic geography, it is possible to assert three main approaches to the study of evolution: generalized Darwinism, the theory of complex adaptive systems, and path dependence theory. The third approach, considered in the present research discussion, is based on path dependence theory and is concerned with emphasizing the historical 
dimension of economics. Path dependence and lock-in are place-dependent processes and as such require geographical explanation (Martin \& Sunley, 2006).

The discussion of path dependence theory within evolutionary economic geography is a result of integrating evolutionary economics and spatial research. It emphasizes the importance of long-term historical economic development (Lengyel \& Molnar, 2015) by focusing on the effects and impacts of past events and decisions on the present and future economies (Martin \& Sunley, 2010). Path dependence is viewed as a process in which the current situation is dependent on its own history, tough not to the extent that it will eventually return to its previous state. It is characterized by a degree of irreversibility and self-reinforcing mechanisms (Martin R. , 2010). In general terms, path dependence theory has come to signalize to the social sciences that 'history matters' to the development and outcome of social phenomena (Henning, Stam, \& Wenting, 2012).

Evolutionary economic geography literature portrays three forms of path dependence mechanisms. First, path dependence refers to technological lock-in when a specific trajectory results from a historical series of actions from which deviation is not possible despite the opportunity of alternative, and possibly more efficient, technologies. Second, agglomeration effects and positive externalities can reinforce path-dependence as increasing revenue generates positive responses that consolidate development paths that were previously established. Third, the progressive self-reproducing nature of formal and informal institutions, social structure and cultural traits, known as institutional hysteresis, also influences path dependence by stimulating the stabilization and social embeddedness of certain activities (Martin \& Sunley, 2006).

The present research considers the case of Costa Rica's energy sector as an empirical investigation in which the three forms of path dependence theory can be identified regarding technological, infrastructural, institutional and behavioral lock-ins (Stern, 2012). While governments invest in large energy related projects and the corresponding policies required to provide cheap energy access for stimulating economic development and poverty reduction, they risk locking their economies onto energy-intensive pathways (Fouquet, 2016). In countries like Costa Rica where hydropower is dominant and the electricity industry is concentrated and connected with 
related policy decisions, it becomes harder to shift towards potentially different and more efficient energy systems (García, 2014).

\section{Renewable electricity in Costa Rica}

During 2017, Costa Rica's electricity supply was generated by hydropower $(78 \%)$, geothermal (10 percent), wind (10 percent), biomass/so$\operatorname{lar}(>1 \%)$, and fossil fuels $(<1 \%)$ (Pereda, 2017). Thus, renewable sources satisfy over $99 \%$ of the country's electricity needs even though it is intensely based on large hydroelectric plants that do most of the generation. Even though the country has great potential for generating solar energy, it does not take advantage of this condition as only $0.34 \%$ of the energy consumed comes from the sun and continues to have a marginal share within the energy matrix (Lara, 2018).

The Costa Rican case of renewable energy use is noticeable because it does not rely completely on hydroelectricity, a condition that differs from other developing nations with limited resources required to invest in capital-intensive renewables and small energy markets or with strong hydropower potential. Furthermore, the sector is directed by a state-owned firm - the Costa Rican Institute of Electricity (ICE) -, which is a condition considered to be inefficient and prone to risk in developing countries. Even though the country has proven oil and natural gas reserves, it has refused to exploit this kind of investments because of the associated environmental impacts (Wilde-Ramsing \& Potter, 2008).

Alternative renewable sources (i.e. geothermal and wind power) were introduced in the energy matrix as a result of earlier investigational projects and sectorial liberalization reforms which changed the configuration of the national energy system during the late 1990's. The country has been ranked among the top renewable electricity users in the world ever since (García, 2014). Moreover, the provision of greater democratic control over environmental resource allocation and economic development is sought through a political model sustained by means of "participative democracy" or "socially inclusive capitalist development" (Martin E., 2004). However, several actors have scrutinized and questioned this renewable energy model. Despite gradual economic stability and ambitious carbon neutrality goals by 2021, the energy system remains subject to a transport system based on fossil fuel imports and a renewable electricity pathway 
that is at a crossroads. Heavy dependency on hydropower has created unstable energy generation due to rainfall variability and droughts, which has proven to trigger the use of fossil fuels in order to secure the provision of short-term energy (Wilde-Ramsing \& Potter, 2008).

The electricity sub-sector of Costa Rica has been the scenario of important struggles in the last decades and it is close to reaching the goal of $100 \%$ renewable electricity generation, thus being the focus of political actors within the energy field. Generating electricity by means of different sources has impacts that are not only economic (i.e. increasing fossil fuel importation), environmental (i.e. $\mathrm{CO}^{2}$ emissions), and social (i.e. electricity accessibility), but also political because it threatens the country's international reputation and national legitimation and exposes actors' interests. Political conflicts and social confrontations regarding electricity projects in Costa Rica and elsewhere in Latin America evidence how an initial sustainable energy development based on renewable sources such as hydropower have become the new constraint of national energy systems.

García (2014) suggests that the argument of path dependency is a reasonable way to analyze the pathway of energy development. Being an established technology for electricity generation in Costa Rica, hydropower dominates the national energy system and is not expected to decline in the following years. Furthermore, its development actually becomes predictable or even irreversible given the institutional and planning structure of the country's electricity sector. Even though alternative renewable technologies could be of high relevance for the national energy systems, established and long-standing energy institutions restrain their active incorporation.

\section{Path dependence mechanisms within Costa Rica's energy sector}

As mentioned previously, literature concerning evolutionary economic geography portrays three forms of path dependence mechanisms: a) technological lock-in resulting from a historical series of actions from which deviation is not possible despite possible alternatives; b) positive externalities reinforce path-dependence that consolidate development paths that were previously established; and c) institutional hysteresis influences path dependence by stimulating the stabilization and social embeddedness of certain activities. This section contributes with an empirical understanding of these 
three forms of path dependence by identifying actor interactions within Costa Rica's energy sector.

\section{Hydropower as a technological lock-in}

A decade of reforms ending with the Civil War of 1948 gave way to the 'Developmental' era (1950 and 1980) in which the state played a leading role within the country's economy and welfare, including the electricity sector (Bull, 2005) (Vargas, 2002). ICE was created in 1949 as a decentralized vertically integrated public company which currently continues to be the main electricity provider in Costa Rica. Steady increasing rates of electrification, social orientation of electricity tariffs, and improving network development were very important for the State's progress during this era (Vargas, 2002). Other companies (i.e. municipal and cooperative distributors) were also integrated into the model beside ICE in order to achieve the electrification of the country's rural and isolated territories.

Correspondingly, the main goal during the import substitution era was to secure the industrial demand for electricity. Hereafter, hydropower (predominantly large hydroelectric dams) became crucial for this development and welfare orientation, as they appeared to guarantee compelling economics by providing large quantities of electricity at reasonably cheap prices compared with other sources of energy generation at the time (Bradford, 2006). In effect, thermal generation (fossil fuel) was practically unexploited until the 1990's (Wilde-Ramsing \& Potter, 2008).

The generation of electricity by means of hydropower possessed compelling economic advantages that assured the necessary energy for domestic industry and ongoing electricity network developments within the context of Costa Rica's "developmentalist state", (Vargas, 2002). Providing large quantities of relatively cheap electricity evolved sufficiently to create a technological lock-in on hydroelectricity generation that is now difficult to reverse. This lock-in condition is currently being reinforced from a political perspective as well, as the country requires a strong share of hydropower in order to match increasing energy demand at competitive prices indispensable for Central America's regional electricity market and Costa Rica's intention of gaining access to the Organization for Economic Co-operation and Development (OECD). 
Despite the opportunity for sturdier contributions of alternative renewable technologies performing better in terms of reducing risk associated with climate change, impacts on ecosystems, water reservoirs and indigenous communities, as well as the increased demand for water resources; the lock-in on hydropower persists and deviation is not foreseen as possible. The drivers of this condition include economies of scale, learning outcomes and coordination effects. Though less explored, vested interests institutionalized over time within the electricity sector also upheld hydroelectricity development.

\section{Positive externalities reinforcing path dependence}

In the context of Costa Rica's energy production and economic development, hydropower became extremely important for two basic reasons: first, guaranteeing power supply for the domestic industrial demand and for ongoing electrification development; and second, to maintain socially oriented tariffs favoring residential consumers, rural areas, and some industrial sectors (García, 2012).

During the nineties, liberalization reforms applied within the country's energy sector aimed at privatizing electricity generation are considered as a critical juncture for the technological pathway (path dependence) based on hydropower. In accordance with past trajectories, the process of liberalization reforms was carried out gradually. Reforms targeting the energy sector implemented during the administrations of ex-presidents Rafael Angel Calderón Fournier (1990-1994) and Jose María Figueres Olsen (1994-1998) were the most significant. These included the incorporation of private sector participation or co-generation and a tariff system creating competition amongst electricity generators.

During the administration of ex-president Miguel Angel Rodríguez Echeverría (1998-2002), a bill package labeled as "ICE Combo", proposing to reform legislation regarding ICE and the energy/telecommunication sector, resulted in political struggles and large scale social protests which obliged its withdrawal. Such initiatives affronted strong opposition from a large part of the public (Hoffman, 2007), while limiting ICE's finances (Merino, 2003). These episodes evidenced a political scenario in which the interests of the domestic elite and the goals of ICE were on different sides (Bull, 2005). 
The mayor impacts of the reforms carried out during this period were the diversification of the energy generation structure in regards to the nature of the producer ( $14 \%$ of the installed capacity was then owned by private producers), as well as generation by means of new sources (i.e. geothermal, wind, and biomass). Hence, the private sector obtained a share in energy generation activities, which they did not have before. ICE's autonomy was reduced due to re-centralization efforts on behalf of political elites, debt crisis, and structural adjustment programs. Environmentalist groups and consumers' began playing a more active role, while labor unions saw their influence reduced (García, 2014).

Nevertheless, this period witnessed how ICE continued with the implementation of large hydropower plants, while the private sector developed several small and medium scale projects as a result of the segmentation and division schemes that were promoted (Vargas, 2009). Hydropower continued to be the chief source of electricity for both private and public sectors, while geothermal and wind energy became part of the energy system with limited shares. Solar technologies represented an insignificant share of the energy matrix, limited to small or niche applications (García, 2014).

This research pinpoints the liberalization reforms previously discussed as a process triggering mechanism that reinforced the path dependence trajectory favoring hydropower in Costa Rica's energy sector. The path has not only been reproduced ever since, but has also created agglomeration effects on hydropower (e.g. increasing run-of-river hydroelectricity plants), positive externalities through policies incorporating new actors (e.g. private investors), and private profits obtained by means of hydroelectricity generation.

On the other hand, Costa Rica lacks the activation of additional policies that incorporate and sponsor new technologies. As reflected in the country's climate change strategies, the governmental standpoint reproduces a direct connection between the promotion of alternative renewable sources with financial incentives and associated policies encouraging private sector participation. The argument behind this is that private investment is necessary given ICE's financial limitations to initiate these transformations (Castro, Porras, \& Jiménez, 2009). 
Daniela García-Sánchez, Daniel Francisco Avendaño-Leadem. Transición energética y dependencia de la trayectoria: el caso de Costa Rica

\section{ICE's institutional hysteresis}

Hydropower has been more than just an energy source for Costa Rica as ICE has been more than just a public electricity provider. Between the fifties and eighties, ICE gained good reputation and credibility regarding its efficiency and technical standards. The autonomy granted to this entity at the time not only strengthened its leadership in the energy sector, but also gave way to a political actor with significant participation in shaping future policies. During the beginning of the 21 st Century the institute was actually considered as "the last refuge of state ownership in Latin Ameri$c a "$ (Bull, 2005, p. 82).

With the subsequent implementation of liberal reforms in the nineties, private producers obtained a share in energy generation activities and hence ICE's self-ruling condition was reduced. Nevertheless, energy production and distribution continues to be led by ICE, together with municipal and rural cooperative partners and some smaller private generators. Despite Costa Rica's energy model being questioned in the last years by those advocating for more private and sustainable generation, ICE continues to be a leader in the country's energy sector (García, 2014).

Even though this public entity is also considered the institutional entrepreneur prompting the initial experimental stages of non-conventional energy sources (i.e. wind and geothermal), alternate domestic entrepreneurship is still incipient. Additionally, resource allocation and policy backing towards these sources has not been formally fomented. Despite the country gaining international recognition for its successful implementation of policies in line with the global climate change strategy based on offset emissions (i.e. carbon neutral commitment by 2021) and selling carbon certificates in the global carbon market, diversification of renewable sources is not considered urgent since the current institutional pathway based on hydropower is already low carbon based.

Costa Rica's path dependent trajectory on hydropower is thus solidified by means of ICE's institutional hysteresis, meaning there is a progressive self-reproducing nature of this organization within the country's social structure and even cultural traits. This is translated in evolutionary economic geography as a case of institutional inertia causing stabilization, persistence and loss of institutional flexibility, thus strengthening the prevailing path dependence on hydropower over alternative renewable sources. 


\section{Conclusions}

Costa Rica is considered to be a leader in renewable energy use since over $90 \%$ of its electricity has been produced for over a decade with renewable sources, mainly hydroelectricity. Alternative renewable sources, such as geothermal and wind power, were introduced in the national energy system as a result of previous experimental projects and sector liberalization reforms during the late 1990's. However, over two decades after these episodes, alternative renewable technologies remain limited and there is evidence of path dependence on hydropower.

This pathway has its own reinforcing processes that favor hydropower and hinder advancements of other renewable technologies. Interpreting this process by clarifying the interacting conditions and participating actors is an important part of the analytical approach used in this research for the determination of a political outcome. Using path dependence theory developed within evolutionary economic geography and neoinstitutionalist school of thought, the present research offers an explanation of a specific path driven by the impact of historical events.

First, the present analysis identified a condition of technological lock-in within Costa Rica's energy sector. ICE was established during the country's developmental era as an autonomous, vertically integrated public company, and the sole electricity generator. Considering the country's geographical conditions (i.e. topography and rainfall), ICE focused on developing hydropower as a source that guaranteed compelling economics by providing large quantities of electricity at reasonably cheap prices, thus becoming crucial for development and welfare. This technological lock-in condition is reinforced by current policies and energy demands, evolving into a pathway that has not only been difficult to reverse, but has also undermined the opportunity for sturdier contributions of alternative renewable technologies.

Second, positive externalities reinforcing the country's reliance on hydroelectricity generation was basically embedded within two main motives. On one hand, the need to guarantee power supply for the domestic industrial demand and ongoing electrification development, and on the other, maintaining socially oriented tariffs favoring residential, industrial, and rural consumers. On a political side, following the interest and pressure of political elite and supported in the nineties liberalization reforms, 
this meant opening the energy market towards private generation, which was equally based on hydropower. Whether it was for social or political reasons on behalf of the public or private sector, hydropower prevailed as the chief alternative for electricity generation.

The last mechanism of path dependence identified relates to ICE's institutional hysteresis. This entity is not only the leader of the country`s energy sector, but also a powerful political actor in shaping past and future energy related policies. Despite political struggles and debilitation on one side, and socio-environmental concerns and carbon neutral commitments on the other, ICE continues to undergo a process of institutional inertia when it comes to diversifying the country's energy mix. Besides the social and political reasons mentioned previously, this condition is also enrooted in the know-how accumulated and applied within a path based on hydropower.

Securing energy and transforming it for useful purposes plays a major influence on society's economic prosperity, geographical structure and international relations. In today's carbon-constrained world, new approaches - and new geographies - will be required to ensure the availability and accessibility of sustainable energy services. Within this context, the present research contributes with an interpretation of Costa Rica's energy transition and its condition of path dependence in order to favor transition towards an even more sustainable energy system that guarantees universal access to energy services generated by secure and reliable supplies of efficient/low-carbon sources.

\section{References}

Boschma, R., \& Martin, R. (2012). The Handbook of Evolutionary Economic Geography. (R. Boschma, \& R. Martin, Edits.) Cheltenham, U.K.: Edward Elgar Publishing.

Bradford, T. (2006). Solar revolution: the economic transformation of the global energy industry. Cambridge - MA, U.S.A. : MIT Press.

Brenner, N. (2004). New state spaces: urban governance and the rescaling of statehood. Oxford, U.K.: Oxford University Press.

Brenner, N., Jessop, B., Jones, M., \& Macleod, R. (. (2003). State/Space: A Reader. Oxford, U.K.: Blackwell Publishing. 
Bull, B. (2005). Aid, power and privatization: The politics of telecommunication reform in Central America. Cheltenham, U.K.: Edward Elga Publishing.

Castro, R., Porras, J., \& Jiménez, G. (2009). Alternativas para el mejor aprovechamiento de la electricidad en Costa Rica. Ambientales, 37, 3-12.

Emmerson, C., \& Stevens, P. (2012). Maritime Choke Points and the Global Energy System: Charting a Way Forward. Chatham House Briefing Paper. London, U.K.: Chatham House (the Royal Institute of International Affairs).

Fendt, L. (30 de March de 2015). The truth behind Costa Rica's renewable energy. Obtenido de The Guardian: https://www.theguardian.com/ commentisfree $/ 2015 / \mathrm{mar} / 30 /$ truth-behind-costa-rica-renewableenergy-reservoirs-climate-change

Fouquet, R. (2016). Path dependence in energy systems and economic development. Nature Energy, 1. Obtenido de http://eprints.lse. ac.uk/67119/1/Fouquet_Path\%20dependence_2016.pdf

García, D. (2012). Decision making and the energy path towards carbon neutrality: the case of Costa Rica. Berlin Conference on Evidence for Sustainable Development. Berlin, Deutschland: Environmental Policy Research Centre (FFU) - Freie Universität Berlin .

García, D. (2014). Solar energy and the problem of path dependence in Costa Rica's energy system. Hamburg, Deutschland: Dissertation zur Erlangung der Würde einer Doktorin der Wirtschafts und Sozialwissenschaften, Fakultät Wirtschaft und Sozialwissenschaften, Universität Hamburg.

Henning, M., Stam, E., \& Wenting, R. (2012). Path dependence research in regional economic development: Cacophony or knowledge accumulation? Papers in Evolutionary Economic Geography (PEEG). Utrecht, Netherlands: Utrecht University, Department of Human Geography and Spatial Planning, Group Economic Geography.

Hoffman, B. (2007). Why reforms fail: The politics of policies in Costa Rican telecommunications liberalizations (Vol. 47). Hamburg, Deutschland: GIGA Working Papers.

Lara, J. (5 de abril de 2018). Costa Rica desaprovecha potencial para generación de energía solar. La Nación. Obtenido de https://www.nacion.com/elpais/infraestructura/costa-rica-desaprovecha-potencial-para-generacion/ J3NMBMO4KFCKXHVBWHK4IVVUGE/story/ 
Daniela García-Sánchez, Daniel Francisco Avendaño-Leadem. Transición energética y dependencia de la trayectoria: el caso de Costa Rica

Lengyel, I., \& Molnar, E. (2015). The role of path dependence in the local economic transformation. J. Geogr. Inst. Cvijic., 65, 373-390.

MacKinnon, D., Cumbers, A., Pike, A., Birch, K., \& McMaster, R. (2009). Evolution in Economic Geography: Institutions, Political Economy, and Adaptation. Economic Geography, 85(2), 129-150.

Martin, E. (2004). Sustainable development, postmodern capitalism, and environmental policy and management in Costa Rica. Contemporary Justice Review, 7, 153-169.

Martin, R., \& Sunley, P. (2006). Path dependence and regional economic evolution. European Science Foundation Exploratory Workshop on Evolutionary Economic Geography (págs. 1-49). Cambridge: St. Catherine's College - University of Cambridge.

Martin, R., \& Sunley, P. (2010). The place of path dependence in an evolutionary perspective on the economic landscape. En R. Boschma, \& R. Martin, The Handbook of EvolutionaryEconomic Geography (págs. 62 - 92). Cheltenham, U.K.: Edward Elgar Publishing .

Massey, D. (2005). For space. California, U.S.A: SAGE Publications

Merino, J. (2003). Cogeneración eléctrica favorece minorías . Revista de generación eléctrica (Federación costarricense para la conservación del ambiente).

Pereda, O. (19 de February de 2017). Costa Rica: World Power in Renewable Energy. The Costa Rica News. Obtenido de https://thecostaricanews.com/costa-rica-world-power-renewable-energy/

Stern, D. I. (2012). Modeling international trends in energy efficiency. Energy Economics, 2200-2208.

Vargas, L. (2002). Competitiveness, innovation and democracy: Space for clean energy within electricity reforms. Heredia, Costa Rica: Editorial Fundación UNA.

Vargas, L. (2009). Producir más energía: cómo, cuándo y cuánto. Ambientales, 37, 3 - 22.

Wilde-Ramsing, J., \& Potter, B. (2008). Blazing the green path: Renewable energy and state-society relations in Costa Rica. The Journal of Energy and Development, 32, 68-90.

Witt, U. (2003). The Evolving Economy: Essays on the Evolutionary Approach to Economics. Cheltenham, U.K.: Edward Elgar Publishing. 
